\title{
Bronisława Grąbczewskiego postrzeganie Orientu w aspekcie rozważań postkolonialnych
}

\begin{abstract}
The postcolonial aspect of Bronisław Grąbczewski's perception of the Orient. The relations between Poland and Russia have been significantly affected by national liberation conflicts. After the 1863 January uprising, approximately 40,000 Poles were sent into remote parts of Russia. Bronisław Grąbczewski was a January insurgent's son for whom history delivered a very different fate. As a young man, he voluntarily joined the tsar's army, which allowed him to serve far from his motherland. Central Asia was his second home for almost twenty years as he explored it during numerous Russian expeditions, including the two he led himself. Travel diaries are his testimony of these expeditions which show the way he presents the Orient. The analysis of these diaries constitutes excellent material for postcolonial studies.
\end{abstract}

Keywords: Bronisław Grąbczewski, Poland, the Russian Empire, Central Asia, postcolonialism

Historycznym relacjom między Polską a imperium rosyjskim towarzyszyły prawie od zawsze powtarzające się wojny i powstania, wynikające, zwłaszcza od XVIII wieku, z walki Polaków o odzyskanie wolności ojczyzny, która znalazła się pod panowaniem Rosji, Prus i Austrii. Należy podkreślić, że w wyniku rozbiorów naj-

Adres do korespondencji: Instytut Filologii Rosyjskiej i Ukraińskiej UAM w Poznaniu, al. Niepodległości 4, 61-874 Poznań. E-mail: wawerpma@amu.edu.pl. 
większa część Rzeczypospolitej Obojga Narodów (czyli utworzonego w 1569 roku na mocy unii lubelskiej państwa złożonego z Korony Królestwa Polskiego i Wielkiego Księstwa Litewskiego) przypadła terytorialnie właśnie Rosji. W wyniku wolnościowych zrywów jeńcy wojenni, powstańcy, ale i cywilna ludność, którą można było powiązać z powstaniami, zsyłani byli w głąb carskiej Rosji. Po powstaniu listopadowym, które wybuchło w 1830 roku, a zakończyło się w październiku 1831 roku, na Syberię i na Kaukaz władze carskie wysłały od 20 do 30 tysięcy żołnierzy i oficerów polskiej armii oraz około 20 tysięcy cywilów. Równie dużo osób (około 40 tysięcy) zesłano po powstaniu styczniowym, które rozegrało się w latach 1863-18641 .

W odniesieniu do przytoczonych danych historycznych możemy przyjąć, że Polska ze swoją polityką dotyczącą wschodnich sąsiadów, a zwłaszcza Białorusi, Litwy i Ukrainy, z państwa o charakterze kolonialnym stała się w wieku XIX państwem skolonizowanym. Tak postawiona teza wymaga wyjaśnienia. Jak słusznie zauważa Dariusz Skórczewski:

rezerwa w stosunku do wpisania dyskursu postkolonialnego na trwałe w pejzaż polskiej nauki płynie w głównej mierze z zastrzeżeń dotyczących adekwatności kategorii „postkolonialności” wobec polskiego doświadczenia historyczno-kulturowego. Rezerwę tę podsyca sceptycyzm co do naszego statusu jako „kolonii”,

chociaż według krytyków zajmujących się postkolonializmem większość państw na świecie musi zmierzyć się dzisiaj z problemem własnej kolonialnej przeszłości. Ania Loomba podaje wymierne dane: „Do lat 30 . XX wieku kolonie i byłe kolonie stanowiły $84,6 \%$ całej lądowej powierzchni naszego globu. Jedynie części Arabii, Persji, Afganistanu, Mongolii, Tybetu, Chin i Japonii nigdy nie znalazły się formalnie pod europejskimi rządami”’3. Ewa Thompson w książce Trubadurzy imperium. Literatura rosyjska $i$ kolonializm słusznie zauważyła, że

paradoksalnie, biali Europejczycy poddani kolonialnej żądzy Rosji czy Niemiec (czy też, wieki temu, imperialnej Turcji) prawie wcale nic uświadamiają sobie, że w rzeczy samej byli poddanymi kolonialnymi. Do tej pory patrzyli oni na swych rosyjskich czy austriackich, czy niemieckich okupantów jako na narody, które zwyciężyły ich w wojnie, a nie jak na nacje zaangażowane w długoplanowy projekt kolonialny ${ }^{4}$.

Należy w tym miejscu podkreślić, że Polacy nie chcieli się czuć, mimo rozbiorów, krajem skolonizowanym, biorąc pod uwagę zwłaszcza aspekt antropologiczny. Jest to szczególnie widoczne w naszych relacjach z Rosją, co obrazowo zilustrowała Maria Janion, pisząc o naszym powiązaniu z kulturą słowiańską:

${ }^{1}$ R. Stawicki, Zarys dziejów polskich zesłańców do Rosji i Związku Sowieckiego (XVII-XX w.), Warszawa 2009, s. 7-8.

2 D. Skórczewski, Teoria - literatura - dyskurs. Pejzaż postkolonialny, Lublin 2013, s. 96.

3 A. Loomba, Kolonializm/Postkolonializm, przeł. N. Bloch, Poznań 2011, s. 11.

${ }^{4}$ E.M. Thompson, Trubadurzy imperium. Literatura rosyjska i kolonializm, przeł. A. Sierszulska, Kraków 2000, s. 69. 
Jesteśmy krajem postkolonialnym, który jednocześnie - co się nieraz zdarza — odczuwa wyższość wobec swego kolonizatora - Rosji. W tym punkcie czuliśmy się i czujemy Europą zmagającą się z azjatyckim barbarzyństwem. Jako prawdziwi łacińscy, katoliccy, śródziemnomorscy Europejczycy nie możemy za bardzo utożsamiać się ze Słowiańszczyzną, bo to by nas zbliżyło do „gorszości” Rosji. Ale, będąc krajem postkolonialnym, nie jesteśmy przecież prawdziwymi Europejczykami, bo - jako Słowianie - jesteśmy wobec nich wtórni, bo odbiło się na nas rosyjsko-słowiańskie skundlenie. Byliśmy jednocześnie krajem kolonialnym i to kolonizującym pobratymczą Słowiańszczyznę. Do dziś odczuwamy wobec niej wyższość, ale i jakieś pokrewieństwo z jej „niższością"

Podkreślana wciąż w Polsce więź z kulturą łacińską i cywilizacją zachodnioeuropejską nie pozwala przekreślić kulturowej wspólnoty ze Słowianami, co widoczne jest w losach i biografii niejednego obywatela Rzeczypospolitej. W drugiej połowie XIX wieku, po ogłoszonych carskich amnestiach, ci z zesłańców, którzy przeżyli, mogli powrócić do swojej ojczyzny. Nie wszyscy jednak skorzystali z takiej okazji. Niektórzy wygnańcy po latach pobytu w Rosji zasymilowali się, co poskutkowało tym, że postanowili pozostać na obczyźnie. Należy też podkreślić, że Polacy, w kontekście naszych dziewiętnastowiecznych powstań, decydowali się nie tylko na zbrojną walkę z imperium rosyjskim. Wielu ludzi rozpatrywało realizację własnych planów, identyfikując je z pracą na rzecz przyszłej niepodległej ojczyzny. Nie sposób wymienić nazwisk wszystkich spośród wybitnych Polaków, których osobiste losy nie zostały zredukowane do krwawych batalii na barykadach. Było wielu takich, którzy wiedzieli, że w Rosji mogą rozwijać różne talenty, począwszy od handlu i gospodarki, profesji urzędniczej, działalności artystycznej - w dziedzinie malarstwa, muzyki, literatury, pracy w różnych gałęziach nauki, a kończąc na służbie wojskowej, która wielokrotnie łączyła ludzi z dyplomacją. Tego rodzaju życiowe wybory bezdyskusyjnie wpisywały się w rozwój imperium rosyjskiego, co nie zawsze kończyło się pozytywną ich oceną w przyszłości - już w odrodzonej Polsce. Trzeba wziąć jednak pod uwagę, że praca na obczyźnie służyła obu narodom. Innym ważnym faktem jest to, że bardzo wielu Polaków, którzy pracowali w Rosji, nigdy nie wyrzekło się swojego polskiego pochodzenia. Starali się oni pielęgnować rodzimą tradycję i kultywować religię katolicką.

Niezwykle interesującym przykładem historii moralnych i życiowych wyborów jest los Bronisława Grąbczewskiego, urodzonego na Żmudzi 15 stycznia 1855 roku w rodzinie szlacheckiej o głębokich patriotycznych tradycjach. Jego ojciec, Ludwik Grąbczewski, był aktywnym uczestnikiem powstania styczniowego $\mathrm{i}$ jednym $\mathrm{z}$ wielu powstańców zesłanych na Syberię. Majątki rodziny zostały skonfiskowane, a żona Ludwika, Emilia, i ich sześcioro dzieci zostali zmuszeni do opuszczenia Litwy i osiedlenia się w Warszawie. Prawdopodobnie ze względu na fatalną sytuację finansową, w której znalazła się cała rodzina, Bronisław postanowił sam wstąpić do armii rosyjskiej, gdzie po ukończeniu szkoły oficerskiej został oddelegowany do Turkiestanu. Służba w armii carskiej stała się wyborem wielu innych polskich rówieśników Bronisława, ponieważ była to często jedyna okazja dla dzieci rodzin szlacheckich, żeby kontynuować edukację, a w przyszłości zapewnić sobie w miarę przyzwoite warunki

5 M. Janion, Niesamowita Słowiańszczyzna. Fantazmy literatury, Kraków 2006, s. 328. 
materialne. Thompson, rozpatrując problem takiej dobrowolnej emigracji, zauważa, że „Rosjanie witali serdecznie porzucających tożsamość niemiecką, polską, ukraińską, litewską, łotewską czy estońską, by zamienić ją na ich własną. Tacy odszczepieńcy nie tylko byli akceptowani jako Rosjanie [...], ale nawet byli przyjmowani z wdzięcznością"6.

Do problemu „porzucania tożsamości” powrócimy w dalszej części. Natomiast w tym miejscu należy wyjaśnić, co mogło kierować młodym Grąbczewskim. Otóż wstąpił do wojska jako ochotnik, bo przewidział, że będzie mógł wybrać jednostkę, w której miałby służyć. W autobiografii, wydanej po jego śmierci, zatytułowanej Na służbie rosyjskiej (1926), w rozdziale wstępnym Tadeusz Lewandowski informuje czytelników, że Grąbczewski „nawet rusyfikując się, obiecał sobie jedno: nigdy mianowicie nie złamie przysięgi danej ojcu i nie podniesie broni na rodaków. Przysięgi dotrzymał"7. Dotrzymał, ponieważ uzyskał upragniony przydział do jednostki stacjonującej w Azji Środkowej ${ }^{8}$. To wydarzenie wpłynęło na całe jego dalsze życie, czyniąc go jednym z ważnych eksploratorów tej części świata oraz przydzielając mu rolę w tak zwanej wielkiej grze rozgrywającej się między imperiami brytyjskim i rosyjskim.

Kariera Grąbczewskiego potoczyła się stosunkowo szybko, co zawdzięczać mógł swojemu niezwykłemu talentowi zarówno do nauk przyrodniczych i ścisłych, jak również humanistycznych. Opanował wiele języków turkijskich, w tym uzbecki i tadżycki, oraz język perski. Jak podaje Kirył Czistiakow w przedmowie do wydanej w Rosji w 2015 roku książki ДервишГиндукуша, Grąbczewski studiował astronomię na Uniwersytecie w Sankt Petersburgu, a praktyka, którą odbył w Pułkowskim obserwatorium astronomicznym, przyczyniła się w późniejszym czasie do nabycia umiejętności wykonywania geodezyjnych pomiarów w Azji Środkowej ${ }^{9}$. Wszystko to sprawiło, że jeszcze przed czterdziestką dosłużył się szlifów generalskich, a służbę w armii carskiej zakończył w 1906 roku w stopniu generała lejtnanta. Grąbczewski w Rosji pełnił wiele ważnych funkcji, spośród których wymienić można między innymi posadę naczelnika powiatu w Oszu, funkcję komisarza pogranicznego na Amurze, w 1903 roku car Mikołaj II mianował go gubernatorem astrachańskim i hetmanem astrachańskiego wojska kozackiego, zajmował kierownicze stanowisko na Kolei Wschodniochińskiej. Największe jednak dokonania Grąbczewskiego są

6 E.M. Thompson, op. cit., s. 34 .

7 B. Grąbczewski, Na służbie rosyjskiej. Fragmenty wspomnień, Warszawa 1990, s. 5.

8 Dokładne informacje na temat przydziału Grąbczewskiego w Turkiestanie opisuje Adam Pleskaczyński we wstępie do książki, w której po raz pierwszy opublikowany został w Polsce dziennik podróży Bronisława Grąbczewskiego. Rękopis dokumentów Grąbczewskiego ponad sto lat był przechowywany w archiwum Rosyjskiego Towarzystwa Geograficznego w Petersburgu. Zob. A. Pleskaczyński, „Nigdzie ani śladu ścieżki. Środkowoazjatyckie peregrynacje Bronisława Grąbczewskiego 1876-1896”, [w:] W. Popiel-Machnicki, A. Pleskaczyński, K. Pleskaczyńska, Podróże nieodkryte: dziennik ekspedycji Bronisława Grąbczewskiego 1889-1890 jako świadectwo historii i element dziedzictwa kulturowego, Poznań 2017, s. X-XI.

9 М.К. Басханов, А.А. Колесников, М.Ф. Матвеева, Дервиш Гиндукуша. Путевье дневники Центральноазиатских экспедиций генерала Б. Л. Громбчевского, Санкт-Петербург 2015, s. 3.

Miscellanea Posttotalitariana Wratislaviensia 8, 2020

(C) for this edition by CNS 
związane z blisko dwudziestoletnim pobytem w Azji Środkowej, którą przemierzył wzdłuż i wszerz w licznych ekspedycjach. Na szczególną uwagę zasługują dwie wyprawy Polaka, którymi dowodził samodzielnie. W 1888 roku poprowadził ekspedycję do Kandżutu i Raskemu, a w latach 1889-1890 do Darwazu, w Pamiry, do Raskemu i do północno-zachodniego Tybetu. Świadectwem tych niezwykle ważnych i ciekawych przedsięwzięć stały się dwa dzienniki podróżne generała, które zdeponowane zostały w archiwach Cesarskiego Rosyjskiego Towarzystwa Geograficznego w Petersburgu, instytucji, która oficjalnie powierzyła Grąbczewskiemu przeprowadzenie tych ekspedycji. Na szczególną uwagę zasługuje drugi dziennik, który zachował się $\mathrm{w}$ wersji rękopisu nigdy niezredagowanego przez podróżnika. Tym samym jest świadectwem bezpośrednich przekazów człowieka, który opisał swoje wrażenia z odbytej wyprawy.

Dziennik ekspedycji do Darwazu, w Pamir, Raskem i do pótnocno-zachodniego Tybetu w latach 1889-1890 to niezwykle bogate źródło informacji, na które złożyły się bezcenne geograficzne, polityczne, etnograficzne i kulturologiczne notatki, uzupełniane przez autora niemal każdego dnia podróży opisami pomiarów meteorologicznych, hipsometrycznych, topograficznych, zapiskami dotyczącymi zbiorów fauny i flory. Należy pamiętać, że Dziennik Grąbczewskiego miał być przede wszystkim dokumentem odzwierciedlającym prawdziwe zadania, które postawiło przed podróżnikiem imperium rosyjskie. Był przecież oficerem i jego ekspedycja miała mieć charakter czysto wojskowy. Lektura Dziennika pozwala jednak dostrzec nie tylko informacje ważne z punktu widzenia nauki oraz o charakterze wywiadowczym, lecz także literacki talent autora. Podróżnik, gromadząc i opisując fakty, świadomie nie kreował fikcji literackiej, co nie przeszkodziło mu w tworzeniu opisów fabularyzowanego ciągu zdarzeń, nadającego całemu dziennikowi charakteru epickości.

Bardzo ciekawe w tym kontekście wydaje się pytanie, jak Polak „na służbie rosyjskiej" zobrazował eksplorowane przez siebie orientalne kraje Azji Środkowe i czy metodologia postkolonialna może okazać się pomocną w odpowiedzi na nie.

Otóż, jak twierdzi Skórczewski, krytyka postkolonialna stara się w utworach literackich odnaleźć wszystkie te pierwiastki, które pozwolą, „by teksty te odsłoniły przed czytelnikiem wpisany w nie obraz »świata «, zinterpretowanego w zgodzie z implikowanym w nich projektem tożsamościowym" ${ }^{10}$. W przypadku Grąbczewskiego, jak i zapewne innych Polaków, którzy podzielili podobny los, problem tożsamości mógł stanowić nie lada problem. Służąc w carskiej armii i wspinając się po szczeblach kariery zawodowej, autor Wspomnień myśliwskich (1925) musiał mieć ciągle na uwadze, że może być oceniany jako Polak i do tego syn powstańca. Powodzenia w misjach do Azji Środkowej spotykały się z zazdrością i Grąbczewski doskonale wiedział, że w jego otoczeniu są ludzie, którzy tylko czekają na jakiekolwiek jego potknięcie. Przypuszczalnie dlatego na kartach Dziennika ukrywał swoje pochodzenie — na ponad 900 stronach napisanego dobrym językiem rosyjskim rękopisu zaledwie

10 D. Skórczewski, op. cit., s. 39. 
dwa-trzy razy napomknął o swoich korzeniach. Charakterystycznym przykładem takiej wstrzemięźliwości w podkreślaniu polskiej narodowości jest zapis datowany na 24 lutego 1890 roku, kiedy to Grąbczewski miał okazję spotkać się z Karolem Bohdanowiczem, Polakiem, który był uczestnikiem innej rosyjskiej ekspedycji, dowodzonej przez pułkownika Michaiła Piewcowa. Wzmianka o treści: „dowiedzieliśmy się, że Wielka Ekspedycja Tybetańska zimuje w Nija i że inżynier K.I. Bogdanowicz przyjechał teraz do Chotanu. Oczywiście pośpieszyliśmy do miasta, żeby zobaczyć się z rodakiem i dowiedzieć się o położeniu ekspedycji"11 , może zadziwiać swoją lakonicznością i brakiem dalszych informacji. 13 października 1889 roku w Dzienniku pojawiła się następująca nota:

Przed wymarszem angielskiej ekspedycji [dowodzonej przez rywala Grąbczewskiego - oficera armii brytyjskiej Francisa Younghusbanda - przyp. WPM] zrobiłem fotografię grupie połączonych ekspedycji, przedstawiająca żywe zainteresowanie z powodu połączenia do 20 narodowości i najróżniejszych ubiorów. W grupowej fotografii wzięli udział przedstawiciele następujących narodowości: Rosjanin, Polak, Niemiec, Anglik, Afgańczyk, hinduskie plemiona: Gurków, Pathanów i Beludżów; Tybetańczycy: Ladakhowie, Baltistańczycy i Arguńczycy (mieszaniec: ojciec Tybetańczyk, matka Kaszgarka i na odwrót); Darwazowie, Sart, Tadżyk, Kaszgarczyk i Kirgizi z rodów: Kesak, Teit, Najman i Chydyrsza. Czyste pomieszanie narodów na tle objuczonych wielbłądów, jaków i koni (240).

Jest to jedyna adnotacja, $\mathrm{z}$ której wynika, że w jednej ze sfotografowanych ekspedycji brał udział Polak, przy czym Grąbczewski nie wyjaśnił, że był nim on sam. Będąc Polakiem, generał nie chciał, żeby ktokolwiek, w kontekście jego narodowości, podważał charakter prowadzonej przez niego wyprawy i jego lojalność wobec imperium rosyjskiego. Dlatego też w Dzienniku częściej padają stwierdzenia typu: „naczelnicy nie zaryzykowali przepuszczenia mnie, Rosjanina” (114); „poznawszy we mnie Rosjanina” (147); „w stosunku do nas Rosjan” (149), czy „biorąc pod uwage entuzjazm miejscowej ludności do nas Rosjan" (151). Musimy mieć na uwadze, że ten „tożsamościowy kamuflaż” nie przesłaniał tego, jak naprawdę Grąbczewski był postrzegany w kręgach władzy. W oficjalnych depeszach do Petersburga rosyjski konsul w Kaszgarze Mikołaj Pietrowski pisał o Grąbczewskim jako o Polaku. Nie zmieniło się to nawet wtedy, gdy w 1903 roku car Mikołaj II mianował go gubernatorem astrachańskim i hetmanem astrachańskiego wojska kozackiego. We wspomnianej autobiografii Na służbie rosyjskiej Grąbczewski tak skomentował to wydarzenie:

W końcu września powrócił cesarz, a 3 października wyznaczono mi urzędową audiencję z powodu nominacji. Zjawiłem się na nią w mundurze kozaków astrachańskich, z buławą hetmana polnego w ręku. Cesarz przyjął mnie nadzwyczaj uprzejmie, winszował nominacji i rzekł: „Myślałem długo, zanim wybrałem pana na stanowisko hetmana polnego, gdyż ani za mych rządów, ani za śp. rodzica mego, ani za dziadka, ani, o ile pamiętam, za pradziada, nie było takiego zdarzenia, aby Polaka i katolika kiedykolwiek mianowano hetmanem Kozaków, którzy są ostoją tronu i dynastii. Stąd może pan wnosić,

11 W. Popiel-Machnicki, A. Pleskaczyński, K. Pleskaczyńska, op. cit., s. 385. (Dalsze fragmenty z Dziennika B. Grąbczewskiego zamieszczonego w tym źródle będą cytowane z podaniem numeru strony w nawiasach).

Miscellanea Posttotalitariana Wratislaviensia 8, 2020

(C) for this edition by CNS 
jak cenię służbę pańską i jak panu ufam. Wierzę, że zrobiłem wybór dobry, że pan podniesie dobrobyt Kozaków astrachańskich i zasłuży sobie na ich przywiązanie"12.

Z przytoczonych przykładów wynika niezbicie, że Grąbczewski stał się ofiarą historycznych wydarzeń, w wyniku których podmiot literacki jego Dziennika, pozbawiony własnej ojczyzny, zatracił tożsamościową jednobiegunowość. Odwołując się do Frantza Fanona i jego książki Wyklęty lud ziemi, Skórczewski podkreśla, że:

kolonializm pozbawił osobowości skolonizowanego. Depersonalizacja ta odczuwana jest także na poziomie grup, na poziomie struktur społecznych. Skolonizowany naród został sprowadzony do zbiorowości jednostek, które swoje istnienie uzależniają wyłącznie od obecności kolonizatora ${ }^{13}$.

W przypadku treści Dziennika można jednak zaobserwować ciekawe zjawisko. Narrator jest przecież Polakiem, którego ojczyzna została podbita przez imperium rosyjskie. Podczas ekspedycji wypełnia zadania przede wszystkim wojskowe, czyli zmierzające stricte do analogicznego skolonizowania ludów zamieszkujących przemierzane kraje Azji Środkowej. Analiza zapisków podróżnych pozwala zauważyć pewną dozę poczucia historycznej wspólnoty, a nawet empatii do napotykanych ludzi. Praktycznie na każdym kroku czytelnik natrafi na współczujące opisy wszechobecnej biedy kirgiskich i tadżyckich górali, wynikającej nie tylko z braku żyznych terenów i surowości klimatu, lecz także z powodu licznych wojen, podbojów dokonywanych zwłaszcza przez Kandżutów, czy na przykład afgańskiej lub chińskiej ekspansji. Grąbczewski wyraźnie obrazuje to następującym opisem:

Interesujący jest stosunek kaszgarskich władz do swoich poddanych. Kiedy kandżucki chan zaczął z naciskiem żądać zapłacenia corocznej daniny, to aksujscy Kirgizi zatrzymali posłańców chana i wysłali suplikantów do kaszgarskiego Dao-Taja, który poradził im „godzić się z sąsiadami”. Poradę Kirgizi przyjęli do wiadomości i teraz płacą daninę: Chińczykom, Afgańczykom i Kandżutom (222).

Informacja ta jest o tyle ciekawa, że podróżnik zaczyna się dzielić z czytelnikiem swoimi przemyśleniami na temat możliwości zmiany tak nieudolnych lokalnych władz. Z opisu o uciekających przed Afgańczykami Szugnańczykach płyną kolonialne idee:

Wśród uchodźców byli ranni. Wypytując, dowiedzieliśmy się, że to żołnierze, którzy niedawno bili się z Afgańczykami. Poznawszy we mnie Rosjanina, podbiegali i całowali mnie po rękach, kolanach, ubiorze, a gdy się wzbraniałem - całowali konia. Wszyscy szli z pełną wiarą i nadzieją, że Biały Car obroni ich i stanie się ich protektorem w nowej ojczyźnie (147).

Należy podkreślić, że misja Grąbczewskiego dotyczyła właśnie przeanalizowania sytuacji panującej w środkowoazjatyckich chanatach, które imperium rosyjskie gotowe było przygarnąć pod swoją „opiekę". Dlatego też percepcja podróżnika zorientowana jest również na pozyskiwanie informacji przydatnych zwłaszcza z militarnego punktu widzenia w kontekście ewentualnej ekspansji:

12 B. Grąbczewski, op. cit., s. 80.

13 D. Skórczewski, op. cit., s. 200. 
Wrażenia wywołane bucharskim wojskiem - najogólniej niezręczne: ludzie wyglądali na biednych i wycieńczonych. Wiek - od siwobrodych starców do 14-letnich dzieci. Dyscypliny i zwartego szyku w dosłownym tego słowa znaczeniu nie ma. Wszystko to przypominało mi raczej musztrę wiejskich chłopaczków niż musztrę żołnierzy (62).

Można podzielić w tym miejscu punkt widzenia Roberta Younga, który przekonująco twierdzi, że

rządy kolonialne i imperialne [...] systematycznie rozwijały obraz ludów skolonizowanego świata jako gorszych, dziecinnych lub zniewieściałych, niezdolnych do zajmowania się własnymi sprawami (mimo że od tysiącleci doskonale sobie z tym radziły) i dlatego wymagających „ojcowskich” rządów w ich własnym interesie... ${ }^{14}$

Moglibyśmy przyjąć, że Grąbczewski myśli „kolonialnie” tylko w związku z funkcją, jaką mu powierzono, a jako zwykły człowiek stara się na każdym kroku postępować godnie, jak przystało na polskiego szlachcica. Należy jednak zwrócić uwagę, że obok opisów przesyconych troską o uciemiężonych tubylców, obrazów ukazujących trudny los kobiet i dzieci czytelnik znajdzie treści, które bardzo często są charakterystyczne dla zachodnioeuropejskiego, jak również rosyjskiego dyskursu orientalnego. Thompson we wspomnianej książce Trubadurzy imperium sugeruje, że już w rosyjskiej literaturze romantycznej, chociażby u Puszkina czy Lermontowa, znaleźć możemy liczne opisy Orientu, które pisane najczęściej z perspektywy pełniącego trudną i niebezpieczną służbę oficera armii carskiej, przepojone są nierzadko oceną pejoratywną. Tubylcza ludność jest zazwyczaj prymitywna, dzika i tchórzliwa. Charakterystyczny jest dla niej brak higieny i dziecięcy sposób myślenia; jedyną nadzieją może być cywilizacyjna misja Rosji ${ }^{15}$. W ten komentarz wpisuje się też tekst Grąbczewskiego. Na kartach Dziennika znajdziemy liczne opisy, z których wynika, że ludność Azji Środkowej pracuje „w sposób jak najbardziej prymitywny”, posługuje się „prymitywnymi, pierwotnymi narzędziami”, a technika pozyskiwania dóbr naturalnych jest „najprymitywniejszej konstrukcji”. Doniesienia typu: „Ałajscy Kirgizi to prawdziwe dzikusy”, „Aliczurscy Kirgizi w ogóle są strasznymi niegodziwcami i dzikusami”, „dzika i nieuczciwa ludność Pamiru” nie stanowią wyjątku. W nocie datowanej na 17 czerwca 1889 roku podróżnik z kategoryzującą oceną opisał jednego z napotkanych po drodze bucharskich urzędników, stwierdzając, że charakteryzował się on „właściwym sobie azjatyckim chełpliwo-tchórzowskim usposobieniem” (21).

Biorąc pod uwagę fakt dowodzenia przez Grąbczewskiego ekspedycją składającą się z samych mężczyzn, warto zwrócić uwagę na ich stosunek do miejscowych kobiet. Generał doskonale wiedział, że jakiekolwiek próby nawiązania bliższego kontaktu z płcią przeciwną są niedopuszczalne. Bardzo dobitnie świadczy o tym następujący fragment:

14 R. Young, Postkolonializm. Wprowadzenie, przeł. M. Król, Kraków 2012, s. 14.

15 Zob. E. Thompson, op. cit., s. 94. 
Darwaskie kobiety nie zasłaniają twarzy między swoimi, ale od nas uciekały i dokładnie się zakrywały. Próbowałem zrobić fotografię i proponowałem po rublu, ale chętnych nie było. To nie wstyd, lecz bojaźń przed wyśmianiem, że fotografowała się przed kafirami i także przesąd, że razem ze zdjęciem fotografujący zapanowuje nad duszą fotografowanego. Skąd takie sądy - jeden Bóg wie, ale są one także rozpropagowane jak i ogólne przekonanie muzułmańskich kobiet, że na sądzie ostatecznym staną razem z tymi, którzy pozbawili je niewinności (66-67).

Dla Europejczyków hidżab, czyli zasłona twarzy, często traktowany jest jako przejaw patriarchalnego ucisku kobiet. Jak tłumaczy Young, dobrowolny wybór zasłony (co widoczne jest w opisie Grąbczewskiego) należy traktować w społeczeństwach muzułmańskich jako symbol „kulturowej i religijnej tożsamości”, jako opór względem niezachodnich wartości wspólnotowych ${ }^{16}$. Grąbczewski doskonale to rozumiał i szanował, co nie przeszkodziło mu poczynić podczas podróży kilku obserwacji i podzielić się nimi z czytelnikiem: „Kobiety w Darwazie wyróżniają się swoistą amoralnością. Śpią na dachach i oddają się nadzwyczaj łatwo i to za najbardziej błahy prezent, a najczęściej za obietnicę prezentu" (67). Takie informacje często spotykane były u pisarzy-orientalistów. Jak zauważa Loomba, w epokach kolonialnych „nie-Europejczycy, a zwłaszcza kobiety, są stale konstruowani jako nadmiernie pobudliwi i nieokiełznani seksualnie"17.

Dziennik Grąbczewskiego jeszcze jednym nawiązuje do problematyki kolonialnego postrzegania rzeczywistości. Chodzi mianowicie o informacje, które poniekąd wpisują się w historię rosyjskiego podboju krajów Azji Środkowej. Thompson, powołując się na badania Edwarda Allwortha, podkreśla, że

skoro tylko Rosjanie ustanowili swą obecność militarną w Azji Środkowej w latach 60. oraz 70. XIX wie$\mathrm{ku}$, rozpoczęło się zbieranie łupu wojennego. „Od najwcześniejszych dni inwazji rosyjskiej, władze okupacyjne i ich podwładni zebrali tysiące środkowoazjatyckich przedmiotów wszelkiej wielkości i rodzaju jako trofea bądź łup, który odtransportowali do St. Petersburga lub Moskwy"18.

Członkowie ekspedycji Grąbczewskiego do Darwazu, w Pamiry, do Raskemu i do północno-zachodniego Tybetu dalecy byli wprawdzie od okradania rdzennej ludności i jakiekolwiek przejawy takiego procederu były surowo karane przez dowódcę. Należy jednak podkreślić, że Grąbczewski, wypełniając misję wojskową pod przykrywką zadań zleconych oficjalnie przez Rosyjskie Towarzystwo Geograficzne, dokładnie się z nich wywiązywał i sumiennie katalogował zbiory etnograficzne, archeologiczne, przyrodnicze zarówno z pierwszej, jak i drugiej dowodzonej przez siebie ekspedycji. W 1888 roku z wyprawy do Kandżutu i Raskemu przywiózł między innymi „22 wypreparowane skóry ssaków wraz z czaszkami, 8 okazów zwierząt zabezpieczonych w słojach ze spirytusem, 116 skórek upolowanych ptaków, zbiór 42 gadów i 15 ryb, [...] 120 przedmiotów z ubrania, broni i przedmiotów codzien-

\footnotetext{
16 Zob. R. Young, op. cit., s. 97.

17 A. Loomba, op. cit., s. 167.

18 E. Thompson, op. cit., s. 179-180.
} 
nego użytku Kandżutów"19. Z drugiej ekspedycji do zarządu towarzystwa geograficznego w Petersburgu trafiły

trzy wielkie skrzynie ze zbiorami zoologicznymi, kolekcja jajek, kolekcja gadów i płazów, niewielki zielnik, ogromna kolekcja entomologiczna, składająca się z 36 tysięcy chrząszczy, niewielka kolekcja geologiczna, „wzory wszystkich znanych wówczas w Kaszgarii pokładów nefrytu wraz z kolekcją narzędzi do obrabiania tego minerału" 20 .

Grąbczewski zebrał również pokaźną kolekcję fotografii własnoręcznie zrobionych na szklanych płytkach, będących doskonałym dokumentalnym materiałem krajoznawczym. Duże wrażenie na czytelniku mogą wywrzeć opisy niekończących się polowań, które były pasją generała. Z jego punktu widzenia były one sposobem uzupełniania prowiantu ekspedycji, ale także możliwością pozyskiwania ciekawych okazów fauny, która spreparowana trafiała do jego zbiorów.

Nadmienić należy, że generał nigdy nie dystansował się od kultury etnicznych ludów Azji Środkowej, która przez wielu innych eksploratorów Orientu często uznawana była za mało wartościową. Grąbczewski, pasjonując się turkijskimi językami, wynotowywał nieznane sobie słownictwo z kandżuckich, wachańskich, jazgulemskich i innych narzeczy. Notował treści zasłyszanych pieśni ludowych, poezji, spisywał baśnie i legendy, pieczołowicie opisywał lokalne rytuały, tańce, zabawy. W kontekście dzisiejszych studiów postkolonialnych tego rodzaju zbiory traktowane są jako bogate źródło wiedzy.

Całościowy wkład Grąbczewskiego w próbę skatalogowania skolonizowanych ludów Azji Środkowej był dla jego protektorów ważny, wpisujący się w procesy imperialnej polityki rosyjskiej.

Reasumując, można stwierdzić, że Bronisław Grąbczewski jest przykładem Polaka, którego burzliwe wydarzenia historyczne zmusiły do dokonania bardzo trudnego wyboru moralnego, wymagającego niejednokrotnie ukrywania prawdziwej tożsamości. Podjęte decyzje pozwoliły mu zrealizować młodzieńcze marzenia o podróżowaniu, stać się niezłomnym dyplomatą oraz znanym i cenionym na świecie badaczem i odkrywcą. Jest on też doskonałym przykładem pisarza, w którego dorobku zaobserwować można społeczno-kulturowe przeciwstawności, pojawiające się w procesie analizowania problematyki relacji kolonizator-skolonizowany.

\section{Bibliografia}

Bashanov, Mihail K., Aleksandr A. Kolesnikov, Mariâ F. Matveeva. 2015. Derviš Gindukuša. Putevye dnevniki Central'noaziatskih èkspedicij generala B. L. Grombčevskogo. Sankt-Peterburg: Nestor-Istoriâ. [Басханов, Михаил К., Александр А. Колесников, Мария Ф. Матвеева. 2015. Дервиш Гиндукуша. Путевые дневники Центральноазиатских экспедиций генерала Б. Л. Громбчевского. Санкт-Петербург: Нестор-История].

19 A. Pleskaczyński, op. cit., s. XIX.

${ }^{20}$ Ibidem, s. XXIV. 
Grąbczewski, Bronisław. 1990. Na służbie rosyjskiej. Fragmenty wspomnień. Warszawa: Prześwit.

Janion, Maria. 2006. Niesamowita Słowiańszczyzna. Fantazmy literatury. Kraków: Wydawnictwo Literackie.

Loomba, Ania. 2011. Kolonializm/Postkolonializm. Przeł. Natalia Bloch. Poznań: Wydawnictwo Poznańskie.

Pleskaczyński, Adam. 2017. „Nigdzie ani śladu ścieżki. Środkowoazjatyckie peregrynacje Bronisława Grąbczewskiego 1876-1896” (Wstęp). W: Wawrzyniec Popiel-Machnicki, Adam Pleskaczyński, Konstancja Pleskaczyńska, Podróże nieodkryte: dziennik ekspedycji Bronisława Grąbczewskiego 1889-1890 jako świadectwo historii i element dziedzictwa kulturowego. Poznań: Wydawnictwo Naukowe UAM.

Skórczewski, Dariusz. 2013. Teoria - literatura - dyskurs. Pejzaż postkolonialny. Lublin: Wydawnictwo KUL.

Stawicki, Robert. 2009. Zarys dziejów polskich zesłańców do Rosji i Związku Sowieckiego (XVII-XX w.). Warszawa: Kancelaria Senatu.

Thompson, Ewa. 2000. Trubadurzy imperium. Literatura rosyjska i kolonializm. Przeł. Anna Sierszulska. Kraków: Universitas.

Young, Robert. 2012. Postkolonializm. Wprowadzenie. Przeł. Marek Król. Kraków: Wydawnictwo Uniwersytetu Jagiellońskiego.

Przyjęto do druku/Accepted for publication: 31.11.2019

Miscellanea Posttotalitariana Wratislaviensia 8, 2020

(C) for this edition by CNS 